\title{
Le Pacte Philippe
}

\section{Alfred Hornung}

Philippe Lejeune's amazing career spans nearly half a century in which he has influenced and guided the teaching and research of "writing one's life." From the magisterial oeuvre of Le pacte autobiographique (1975) via an amazing series of impressive volumes on all forms of life writing to the recent Ecrire sa vie (2015a) he has constantly inspired the work of writers and critics of auto/biography worldwide. Among the many endearing and appreciating appellations for him the title of "le pape de l'autobiographie" seems to be the most appropriate (Lejeune 2015a, 7). The pope reaches out to the whole world from his Holy See in Rome and advises his followers and like-minded people regardless of race, class, and gender in a universal language. His disciples spread the good tidings. In Philippe Lejeune's case the Holy See is the all-inclusive egalitarian union of auto/biography enthusiasts, and it is not in Rome but in Ambérieuen-Bugey, Département Ain in the Auvergne-Rhône-Alpes region.

In Le pacte autobiographique, Philippe Lejeune established a relationship between the text of an autobiography and its reader based on the ineluctable agreement for the process of reading that the author of the text is a real person writing his life. I would like to use this fundamental assumption established by the renowned autobiography critic for the world of scholarship and suggest its application to Philippe the human being and academic who enlightens the global community of life writers and engenders their efforts. It is the physical and emotional reality and the felt presence of the author and critic which animate our activities in life writing. Following Jean-Paul Sartre's maxim in L'existentalisme est un humanisme, "l'existence précède l'essence" (1946), I would like to posit: "le pacte Philippe précède le pacte autobiographique."

To prove my point, I will review the stages of my personal encounters with Philippe in which "le pacte Philippe" established itself. The first time I met Professor Philippe Lejeune, the famous French autobiography critic, took place at the important autobiography conference organized by the young and 
aspiring Chinese scholar Zhao Baisheng at the University of Peking in 1999. Baisheng had used the one-hundred-year anniversary of his University to assemble the most well-known North American, Australian, and British autobiography scholars, and of course Philippe Lejeune for an innovative EastWest discussion of autobiography. I also received an invitation, maybe because I had run two international autobiography conferences with my Romance literature colleague Ernstpeter Ruhe, in which we included Francophone and Anglophone authors, such as Alain Robbe-Grillet, Assia Djebar, Maxine Hong Kingston, and Michelle Cliff (cf. Hornung/Ruhe 1992; 1998). Zhao Baisheng's Beijing conference proved to be very ambitious on all accounts, because he combined the invitation of international autobiography scholars with the annual meeting of the imposing Chinese Autobiography Association. While the international guests communicated in English or French, their speeches had to be translated into Chinese. The Chinese workshops were conducted in Mandarin and obviously represented insurmountable language problems for the Westerners. Inspired by Baisheng's enthusiasm and drive we sat down to pave the way for the formation of a professional alliance of people interested in things autobiographical, which eventually became the International Auto/ Biography Association (IABA) with the first headquarters in Beijing. I remember that Philippe played an essential part in the discussions over the format and the principles of such an association. At the time, he had already transcended the narrow boundaries of an academic field of research by founding the "Association pour l'autobiographie et le patrimoine autobiographique (APA)" in 1992, outside of and away from the university centres in Paris, in the small town of Ambérieu-en-Bugey between Lyon and Geneva. When he left his chair of French Literature at the l'Université Paris-Nord in 2004, he made this communal centre of auto/biography practice and research his "papal" autobiography residence.

The philosophy of APA contained many of the features of the nascent IABA and more. It simply stopped the exclusive focus on the classic canon of autobiography from Saint Augustine via Benjamin Franklin, JeanJacques Rousseau, and Johann W. Goethe to Michel Leiris, Gertrude Stein, Primo Levi, or Peter Handke and extended the field to all areas of writing one's life without regard for the autobiographer's status. After twenty-five years of its existence the elaborate APA homepage lists its organs of publication, objectives and mission:

L'APA est une association de personnes intéressées par la démarche autobiographique, dont l'objectif premier est la collecte, la conservation, la valorisation de textes autobiographiques inédits. Pour mener à bien cet objectif elle accueille, lit, conserve tous les documents autobiographiques inédits (récits, correspondances, journaux) qu'on veut bien lui confier. (http://autobiographie.sitapa.org) 
This liberation of the genre of autobiography, which is reflected in the aptly named journal La Faute à Rousseau and in the slash between auto and biography chosen for IABA, also influenced the question of language, so imposing in the Chinese language environment of Beijing. In our conversations Philippe spoke French, mostly, also as a counterpart to the lingua franca of English. The choice of his native language later received more prominence when Zhao Baisheng introduced the performance of national songs at the conference dinner. In a sort of autobiographical act, participants grouped around a national song, varying between strong teams from the US, Canada, and Australia to single national voices from less represented countries, sometimes aided by friendly polyglot participants. Philippe's chansons could always count on such support, obviously evoked by the emergent "pacte Philippe."

The next stage in the formation and realization of "le pacte Philippe" was the international autobiography conference, organized by Susanna Egan, Gabi Helms, and Shirley Newman in Vancouver at the University of British Columbia in 2000, renamed the second IABA conference after the Beijing experience. Philippe, as one of the keynotes, spoke on the function of death and survival implicit in the writing of journals (Lejeune and Lodewick 2001), and was joined in his usage of the French language by Francophone Canadian scholars. The question of language and the focus on autobiographical documents in nations and languages other than English was again prominent in discussions about the further progress of IABA. Early on, Philippe saw the danger of an exclusive focus of auto/biography studies on literature in English and in line with his APA spirit urged the inclusion of all autobiographical expressions. The translation of this all-inclusive and libertarian belief entered the egalitarian constitution of IABA without any officers or fees. The Listserve established and run by Craig Howes at the University of Hawai'i at Mānoa since 2000 became the digital medium, whose value for autobiographical statements Philippe prefigured (see "A l'ère du numérique," in Lejeune 2015a, 103-120). Overlooking the Pacific Ocean from the height of the University of British Columbia, the second stage of "le pacte Philippe" evolved.

The next three IABA conferences organized in Melbourne, HongKong, and Mainz addressed intergenerational, intercultural, and interdisciplinary topics in response to urgent issues and theoretical needs in Australia, China, and Germany. The $6^{\text {th }}$ IABA conference took place in Honolulu in 2008. Craig Howes and his colleagues at the Center for Biography recognized in their choice of topic the multi-ethnic and multilingual constitution of the Hawaiian Islands on the one hand and the insistently virulent issue of "Language" reverberating not only in IABA circles. In his keynote, Philippe Lejeune raised the pertinent question: 
"Le Moi est-il international?" in cooperation with his translator, retired professor of French at the University of Hawai'i Jean Toyama (Lejeune 2009). In view of the many different languages spoken on Hawai'i the need for translation emphasized the collective and collaborative effort in the IABA community. Using one's own national language hence turns out to be a relational act of scholarship and at the same time creates a bond of friendship and alliance. This new dimension of "le pacte Philippe," demonstrated vividly and effectively in Philippe's cooperation with his translator Jean Toyama, displayed itself in small group excursions to other islands, such as the volcanic Big Island. At the end of our remarkable stay in Hawai'i nobody questioned the internationality of the "Moi" any more, trusting in the aid of linguistic and cultural translators.

The experience of Hawai'i as well as the numerous presentations on auto/biography and language were the background and reason for the formation of regional chapters of IABA. Monica Soeting approached me after the conference in Hawai'i to think about the creation of a European chapter of IABA, an idea which would take up Philippe Lejeune's longtime plea for the recognition of national documents within an international context. Except for Great Britain, Ireland, and Malta, there are no other Anglophone countries in Europe. The formation of a European region of auto/biography studies would not only foreground the language question but would also bring into focus new topics of auto/biography in Central and Eastern Europe. The first conference of IABA Europe, convened by Monica Soeting, Anneke Ribberink, and Marijke Huisman in Amsterdam in 2009, revealed a new landscape of autobiography research in terms of topics and languages spoken. For the first time since the foundation of IABA, a number of colleagues from Eastern Europe participated in an IABA event giving papers on new traces of life writing in the post-communist era of their countries (see Huisman et al., 2012). This effect even intensified during the second IABA-Europe conference, organized by Leena Kurvet-Käosaar in Tallinn in 2011. Philippe Lejeune was one of the keynote speakers.

The conference in Tallinn was the first one taking place in an Eastern European country, which allowed many colleagues in the neighborhood to travel to Estonia. The Baltic states had only achieved their independence from Soviet rule in 1991 and were trying to reconnect to their cultural traditions before the occupation. The presence of Russian Orthodox churches in Tallinn, the architectural traces of the German Hanse, and continuous interactions with Scandinavian countries signaled the intercultural network in which the Estonian independence had to affirm itself. At the end of the conference, Leena, our Estonian host, took us to the University of Tartu, where she now teaches in the Institute of Cultural 
Research and Arts. There she showed us the products of a joint project in Estonian schools where children were asked to solicit life stories from their grandparents in which they relate their lives during the Soviet occupation. This is the beginning of an archive and archival work in the manner that Philippe Lejeune has pursued and encouraged over the years. In the European Journal of Life Writing he records the initial meeting in Amsterdam on June 5, 2015 for the foundation of a network of European diary archives:

\begin{abstract}
About fifteen people from autobiographical archives throughout Europe have come together at the Meertens Institute, which houses the Nederlands Dagboekarchief, founded in 2010 by Mirjam Nieboer and Monica Soeting. We are in Amsterdam to found a network of European diary archives and collections. (Lejeune, 2015b)
\end{abstract}

In Tallinn, Philippe Lejeune's choice of topic for his keynote was a passionate and inspiring reading of passages from Jean-Jacques Rousseau's autobiography Confessions. The beginning of this autobiography seems to be a perfect formulation of Lejeune's theory expounded in Le pacte autobiographique:

Je forme une entreprise qui n'eut jamais d'exemple, et dont l'exécution n'aura point d'imitateur. Je veux montrer à mes semblables un homme dans toute la vérité de la nature; et cet homme, ce sera moi.

Moi seul. Je sens mon cœur, et je connais les hommes. Je ne suis fait comme aucun de ceux que j'ai vus; j'ose croire n'être fait comme aucun de ceux qui existent. Si je ne vaux pas mieux, au moins je suis autre. Si la nature a bien ou mal fait de briser le moule dans lequel elle m'a jeté, c'est ce dont on ne peut juger qu'après m'avoir lu. (Rousseau, 1996)

While Rousseau clearly locates himself as the author writing his own life, this opening passage also stands for "le pacte Philippe." "Je sens mon coeur, et je connais les hommes" is precisely the emotional bond and the professional alliance which have distinguished Philippe Lejeune's life and career. When I was about to give my keynote address the next day on "Return Visits: The European Background of Transcultural Life Writing” (Hornung, 2013), he walked up to me and wished me good luck: "Bonne Chance." At that moment, I felt the powerful presence of "le pacte Philippe" and its profound effect on my presentation. I know that many colleagues have had similar experiences of this true scholar in its original sense as derived from the Latin schola standing for a school of auto/biographees. 
This school of auto/biographees, of practitioners, readers and critics of all forms of auto/biography, communicates "le pacte Philippe" transnationally, forming a universal bond. It was the personal relation of Paul John Eakin with Philippe, established during John's time in Paris, which led to the English language translation of a collection of Philippe Lejeune's work On Autobiography (1989), concluding with a chapter on "Teaching People to Write Their Life Story" (216-31). There is no doubt that Eakin's own impressive work on autobiography profited from the cooperative spirit of "le pacte Philippe." A similar kind of engagement in "le pacte Philippe" motivated Jeremy Popkin and Julie Rak twenty years later to edit and introduce Lejeune's work On Diary, translated by Kathy Dumin (2009). Again, both editors had personal connections with Philippe and wanted to make his research available to the English language community. This dissemination of Philippe Lejeune's work is also in the service of extending "le pacte Philippe." From the center of Ambérieu-en-Bugey it seems to emanate in concentric circles encompassing all autobiography activities around the globe.

Life writers and life writing scholars are inspired by Philippe Lejeune's example and encouragement. All members of IABA and its regional chapters in Europe, the Americas, Asia-Pacific, and Africa as well as all other auto/biographees in associations or as individuals have profited from his ideas and are deeply indebted to him for offering us "le pacte Philippe." We owe him gratitude for his lifelong service and ultimately for his collegiate spirit and autobiographical friendship.

\section{WORKS CITED}

Hornung, Alfred. "Return Visits: The European Background of Transcultural Life Writing." European Journal of Life Writing 2 (2013): T10-T24.

Hornung, Alfred and Ernstpeter Ruhe, eds. Autobiographie $\mathcal{E}$ Avant-garde: Alain Robbe-Grillet, Serge Doubrovsky, Rachid Boudjedra, Maxine Hong Kingston, Raymond Federman, Ronald Sukenick. Tübingen: Narr, 1992.

Hornung, Alfred and Ernstpeter Ruhe, eds. Postcolonialism and Autobiography: Michelle Cliff, David Dabydeen, Opal Palmer Adisa. Amsterdam: Rodopi, 1998.

Hornung, Alfred and Ernstpeter Ruhe, eds. Postcolonialisme \& Autobiographie: Albert Memmi, Assia Djebar, Daniel Maximin. Amsterdam: Rodopi, 1998.

Huisman, Marijke, Anneke Ribberink, Monica Soeting, and Alfred Hornung, eds. Life Writing Matters in Europe. Heidelberg: Universitätsverlag Winter, 2012.

Lejeune, Philippe. On Autobiography. Transl. Katherine Leary. Ed. with Foreword by Paul John Eakin. Minneapolis: University of Minnesota Press, 1989.

Lejeune, Philippe. Le pacte autobiographique: Nouvelle édition augmentée. 1975. Paris: Édition du Seuil, 1996.

Lejeune, Philippe. On Diary. Transl. Kathy Dumin. Ed. with introductory essays by Jeremy Popkin and Julie Rak. Honolulu. University of Hawai'i Press, 2009. 
Lejeune, Philippe. "Le Moi est-il international?" Biography 32.1 (2009): 1-8.

Lejeune, Philippe. Ecrire sa vie: Du pacte au patrimoine autobiographique. Paris: Éditions Mauconduit, 2015a.

Lejeune, Philippe. "Europe's Treasure Hunters: The Founding of a Network of European Archives and Collections." The European Journal of Life Writing 4 (2015b): R16-R18.

Lejeune, Philippe, and Victoria A. Lodewick. "How Do Diaries End?" Biography 24.1 (2001): 99-112.

Rousseau, Jean-Jacques. Confessions. Ed. Bernard Gagnebin. 1782-1789. Paris: Gallimard, 1996.

Sartre, Jean-Paul. L'existentialisme est un humanisme. 1946. Paris: Gallimard, 1996.

\section{ABOUT THE AUTHOR}

Alfred Hornung is Research Professor of English and American Studies and Speaker of the Obama Institute at the Johannes Gutenberg University of Mainz. He held guest professorships at various European, American, Canadian, and Chinese universities. He was a fellow at Harvard, Yale, the National Humanities Center in North Carolina, and is a member of the Center for Cross-cultural studies at Peking University. His publications are in the field of modernism, postmodernism, life writing, intercultural, and transnational studies. From 1991-2002 he was the general editor of the journal Amerikastudien/American Studies. He is an editor of the American Studies Monograph Series, the Journal of Transnational American Studies and on the editorial board of several journals, including Atlantic Studies and Contemporary Foreign Literature (Nanjing). He served as President of MESEA (the Society for Multi-Ethnic Studies: Europe and the Americas, 2000-2004), as President of the German Association for American Studies (2002-2005), as a member of the International Committee of the ASA. He is a founding member of IABA and of IABA-Europe and on the editorial board of Life Writing in Europe, Journal of Life Writing, a/b: Auto/Biography Studies. In 2013 he received the Carl Bode-Norman Holmes Pearson Prize of the American Studies Association. In 2014 he was elected a member of Academia Europaea, in 2017 a member of the Advisory Board of the Institute of World Literature (Harvard). His latest life writing publications are: with Zhao Baisheng Ecology and Life Writing (2013)-Chinese translation (2016), American Lives (2013), with Carsten Heinze Medialisierungsformen des (Auto-) Biographischen [Media and (Auto-)Biographical Expressions] (2013), "Life Sciences and Life Writing." Anglia 133.1 (2015): 1-16, Jack London: Abenteuer des Lebens (Darmstadt: Lambert Schneider, 2016), "North American Autobiography." Handbook Autobiography/Autofiction. Ed. Martina Wagner-Egelhaaf, 3 vols., Berlin: deGruyter, 2018, vol. 2. 